\title{
IN VITRO REGENERATION OF SHOOTS FROM NODAL EXPLANTS OF DENDROBIUM CHRYSOTOXUM LINDL.
}

\author{
Saranjeet KAUR* \\ Department of Science, Cordia College \\ Sanghol, District- Fatehgarh Sahib, Punjab, India \\ Received: March 2017; Accepted: June 2017
}

\begin{abstract}
Transverse sections ( $2 \mathrm{~mm}$ thickness) of stem-nodes from in vitro raised seedlings had morphogenic potential on semisolid and liquid Murashige and Skoog medium supplemented with cytokinins $\mathrm{N}^{6}$-benzyladenine (BA $4.44 \mu \mathrm{M}$ ), furfurylaminopurine (KIN $4.65 \mu \mathrm{M}$ ) and auxin $\alpha$-naphthalene acetic acid (NAA $5.37 \mu \mathrm{M})$ individually and in combinations. The regeneration response was influenced by both the type of growth regulator and physical state of the medium. The explants produced either shoot buds on cytokinincontaining media or protocorm-like bodies (PLBs) on NAA containing media both solid and liquid. More $n e o$-formations were produced on liquid media, especially those containing only NAA. They were formed at nodal and inter-nodal regions. The secondary buds were produced on the surface of primary PLBs. The plantlets were developed on MS medium containing banana homogenate $50 \mathrm{~g} \cdot \mathrm{dm}^{-3}$. The current study is the first ever report on successful regeneration of Dendrobium chrysotoxum from stem-node segments.
\end{abstract}

Key words: Dendrobium chrysotoxum, endangered species, species preservation, protocorm-like body, nodal explants

\section{INTRODUCTION}

Dendrobium chrysotoxum belongs to one of the largest group of angiosperms consisting of 25000 species. It is an evergreen, epiphytic sympodial orchid species possessing spikes of 15-20 deepyellow colored aromatic blossoms. The species grows in the tropical to sub-tropical climates at an altitude of 400-1000 meters in north-eastern Indian Himalayas, Bhutan, China, Thailand, and Laos in evergreen semi-deciduous forests (Shukla et al. 1998). D. chrysotoxum also known as golden orchid, and is very popular in floriculture market owing to its charismatic bright yellow-colored flowers. as cut-flower for floral arrangements, corsages, bouquets and as pot plants. The blossoms stay fresh for several days. Apart from its high floricultural value, the species is widely used for medicinal purposes. It is rich in biologically active chemical compounds showing potent antioxidant, immune stimulating, anti-hyperglycemic (Zhao et al. 2007), anti- angiogenic and anti-tumoral activity (Gong et al. 2004). Whole plants are used to extract cytotoxic compound, i.e. 1,4,5-trihydroxy-7-methoxy-9Hfluoren-9-one which is highly anti-carcinogenic (Chen et al. 2008). The fresh or dried stems of this species are used to treat loss of appetite with nausea and impaired vision (Yang et al. 2004).

Owing to its diverse worth (horticultural and therapeutic), entire plants of $D$. chrysotoxum are the target of massive commercial collections, which far exceeds their natural regeneration. As a result, its populations are vanishing swiftly in the wild and has become threatened. As a consequence, species is included in appendix II of the Convention on International Trade in Endangered Species of Wild Fauna and Flora (CITES 2017), along with other orchid species. Therefore, integrated multi-disciplinary approaches are required to save the ever-decreasing populations of D. chrysotoxum. Present efforts are a step forward to propagate the species through tissue culture techniques. In vitro technology offers 
an opportunity for the conservation of gene pools by mass propagating within a short time period. However, the micropropagation techniques for D. chrysotoxum at commercial level do not exist due to lack of efficient and reliable protocols with using different explants. The vegetative propagation through stem-cuttings in nursery beds is time-consuming and not even profitable. Moreover, seedraised progenies are extremely heterozygous and express undesirable genetic variations in the populations. In this condition, use of alternative explants helps in raising innumerable genetically identical clones. So far, the regenerative potential of stemnodes has been positively tested in some orchid species (Arditti \& Ernst 1993; George \& Ravishankar 1997; Vij \& Kaur 1998; Kanjilal et al. 1999; Gangaprasad et al. 2000; Pyati et al. 2002; Decruse et al. 2003; Basker \& Narmatha Bai 2006; Martin 2007; Zhao et al. 2007; Janarthanam \& Seshadri 2008; Medina et al. 2009; Rangsayatorn 2009; Hong et al. 2010; Kaur \& Bhutani 2010).Till date, in vitro propagation of $D$. chrysotoxum was reported only through seeds (immature/mature), shoot-tips and protocorm segments culture (Xu et al. 2001; Roy et al. 2007; Kaur \& Bhutani 2011). The objective of this study was to access the regeneration competence of stemnodes to multiply the $D$. chrysotoxum by subjecting them to varying physical and chemical stimulus in the medium.

\section{MATERIALS AND METHODS}

Dendrobium chrysotoxum plants were obtained from a commercial grower. The plants were replanted in the pots containing the epiphytic substrate such as charcoal, brick, and bark pieces in the ratio of $1: 1: 1$. The top of the potting mix was covered with sphagnum moss to retain the moisture. The plants were maintained in the a greenhouse under natural light conditions with $70 \%$ relative humidity, and $25 / 20^{\circ} \mathrm{C}$ day and night temperature. A voucher specimen (Herbarium number NIP 155) has been deposited in the herbarium of Department of Natural Products Niper, Mohali, India.

The stem-node segments (uninodal, $2-3 \mathrm{~mm}$ thick), procured from 22 weeks old aseptic cultures (raised through asymbiotic seed germination technique) were used as explants. The segments were placed in the Murashige and Skoog (MS) (1962) agarised or in a liquid medium individually and supplemented with growth regulators such as cytokinins [6-benzylaminopurine (BA $-4.44 \mu \mathrm{M})$ or furfurylaminopurine $(\mathrm{KIN}-4.65 \mu \mathrm{M})]$, and auxin [ $\alpha$-naphthalene acetic acid (NAA - $5.37 \mu \mathrm{M})](\mathrm{Hi}-$ Media, Mumbai, India) individually and in combinations. The media were supplemented with $3 \mathrm{~g} \cdot \mathrm{dm}^{-3}$ sucrose (Hi-media, Mumbai, India) and gelled with $0.8 \%$ agar powder (Hi-Media, Mumbai, India).

D. chrysotoxum plantlets $(2-3 \mathrm{~cm}$ in length) consisting of one to two nodes were sub-cultured on MS medium containing as organic growth supplement $50 \mathrm{~g} \mathrm{dm}^{-3}$. (w/v) banana homogenate prepared according to Kaur \& Bhutani (2014). The $\mathrm{pH}$ of the medium was adjusted to 5.7 after adding growth regulators and organic growth supplement. The agarised media were dispensed in the test tubes (25 $\times 150 \mathrm{~mm}$ ) and liquid in $250 \mathrm{ml}$ flasks (Borosil, India) and autoclaved at $121{ }^{\circ} \mathrm{C}$ at the pressure of 1.06 $\mathrm{kg} \cdot \mathrm{cm}^{-2}$ for $15 \mathrm{~min}$. Sterile media were kept at $37^{\circ} \mathrm{C}$ for 2 days to check any further contamination.

The cultures were incubated at $25 \pm 2{ }^{\circ} \mathrm{C}$ under $12 \mathrm{~h}$ photoperiod of $40 \mu \mathrm{mol} \cdot \mathrm{m}^{-2} \cdot \mathrm{s}^{-1}$ light intensity provided by white fluorescent tubes (Fluorescent tubes; Philips India Ltd, Mumbai, India). The liquid cultures were rotated on an orbital shaker at $120 \mathrm{rpm}$. Eight replicates were used for each experiment. To check the reproducibility of the protocol, the experiments were repeated twice and data were compiled.

\section{Observations and statistical analysis}

The experiment was designed following complete randomized design (CRD) with eight replicates per treatment. The effect of medium composition on percentage of regeneration, time of initiation of regeneration response, average number of regenerates induced per explant, and time taken in weeks to form complete plantlets was tested applying Tukey's multiple comparison test $(\mathrm{P} \leq 0.05)$ in one way ANOVA to separate of significantly different groups. The statistical analyses were performed using the SPSS (version 17) software package. (SPSS Inc., Chicago, USA).The results are expressed as mean \pm SD of eight replicates. 


\section{Histological studies}

Histological studies were conducted to trace the origin of the meristemoids. Free hand sections of the responding segments were cut by placing them in a potato pith. Very thin sections, which were able to float on the surface of water, were selected. They were stained with safranine and observed under stereoscopic microscope (Nikon, H600L, Japan).The photographs were taken using a digital camera (Nikon Digital Sight, DS, Ri1 Nikon Corporation, Japan).

\section{RESULTS AND DISCUSSION}

The percentage of regeneration, nature of regenerants and their number varied with the type of growth regulator and physical state of the medium. On the agarised media regenerated from 25 to $75 \%$ of explants (Table 1), whereas regeneration in liquid medium was from 25 to $100 \%$ (Table 2). A survey of literature reveals that liquid cultures are more efficient in inducing proliferations of neo-formations
(Levin et al. 1997; Ziv et al. 1998). In comparison to the solid medium, in the liquid explants stay in close contact with the medium which makes it possible for the uptake of nutrient components more effectively through a whole surface and leads to enhanced shoot and root growth (Smith \& Spomer 1994; Sandal et al. 2001). Moreover, continuous shaking leads to mechanical separation of neo-formations usually developed as clusters (Levin et al. 1997; Ziv et al. 1998). Liquid-agitated cultures are more efficient in promoting growth and multiplication of the shoots by enhancing forced aeration thus providing sufficient oxygen supply to the tissues and nutrient uptake as earlier indicated by Puchooa (2004) in Dendrobium and Malaxis acuminata (Kaur \& Bhutani 2010). In this study, also comparison was made between liquid-agitated medium and liquid static medium of the same composition but it was not included to the presented experiment. In this comparison liquid agitated medium supported better regeneration percentage as compared to liquid static medium.

Table 1. In vitro regeneration response of stem-node segments of D. chrysotoxum in MS agarised medium and its combinations with growth regulators

\begin{tabular}{lcccc}
\hline \multicolumn{1}{c}{ Additives } & $\begin{array}{c}\text { Regeneration } \\
\text { response }(\%)\end{array}$ & $\begin{array}{c}\text { Initiation } \\
\text { of response }(\mathrm{wk})\end{array}$ & $\begin{array}{c}\text { Number } \\
\text { of regenerates }\end{array}$ & $\begin{array}{c}\text { Development } \\
\text { of plantlets (wk) }\end{array}$ \\
\hline NAA & $50.00 \pm 0.57^{\mathrm{b}}$ & $2.50 \pm 0.14^{\mathrm{a}}$ & $3.25 \pm 0.50^{\mathrm{d}^{*}}$ & $12.15 \pm 0.19^{\mathrm{a}}$ \\
$\mathrm{BA}$ & $25.00 \pm 0.50^{\mathrm{a}}$ & $7.17 \pm 0.17^{\mathrm{cd}}$ & $1.75 \pm 0.50^{\mathrm{b} \dagger}$ & $17.65 \pm 0.23^{\mathrm{c}}$ \\
KIN & $75.00 \pm 0.50^{\mathrm{c}}$ & $4.17 \pm 0.17^{\mathrm{b}}$ & $2.00 \pm 0.00^{\mathrm{bc} \dagger}$ & $13.57 \pm 0.20^{\mathrm{bc}}$ \\
$\mathrm{BA}+\mathrm{NAA}$ & $25.00 \pm 0.00^{\mathrm{a}}$ & $6.05 \pm 0.12^{\mathrm{bc}}$ & $2.00 \pm 0.00^{\mathrm{bc} \dagger}$ & $13.47 \pm 0.09^{\mathrm{bc}}$ \\
KIN + NAA & $25.00 \pm 0.00^{\mathrm{a}}$ & $7.05 \pm 0.17^{\mathrm{cd}}$ & $1.00 \pm 0.00^{\mathrm{a} \dagger}$ & $19.10 \pm 0.08^{\mathrm{cd}}$ \\
\hline
\end{tabular}

Note: BA - $4.44 \mu \mathrm{M}, \mathrm{KIN}-5.65 \mu \mathrm{M}, \mathrm{NAA}-5.37 \mu \mathrm{M},{ }^{*}$ protocorm-like bodies, $\uparrow=$ shoot buds. Values in a column with similar superscripts are not significantly different at $\mathrm{p} \leq 0.05$ according to Tukey's test

Table 2. In vitro regeneration response of stem-node segments of D. chrysotoxum in MS liquid (agitated) medium and its combinations with growth regulators

\begin{tabular}{|c|c|c|c|c|}
\hline Additives & $\begin{array}{l}\text { Regeneration } \\
\text { response }(\%)\end{array}$ & $\begin{array}{c}\text { Initiation } \\
\text { of response (wk) }\end{array}$ & $\begin{array}{c}\text { Number } \\
\text { of regenerates }\end{array}$ & $\begin{array}{c}\text { Development } \\
\text { of plantlets (wk) }\end{array}$ \\
\hline NAA & $100.00 \pm 0.00^{\mathrm{d}}$ & $2.02 \pm 0.00^{\mathrm{a}}$ & $20.70 \pm 0.00^{\mathrm{d}^{*}}$ & $\begin{array}{l}\qquad 9.00 \pm 0.00^{\mathrm{a}} \\
\text { (PLBs were transferred to agar- } \\
\text { gelled MS medium containing } \\
\text { NAA and fortified with banana } \\
\text { homogenate }\left(50 \mathrm{~g} \cdot \mathrm{dm}^{-3}\right)\end{array}$ \\
\hline $\mathrm{BA}$ & $25.00 \pm 0.50^{\mathrm{a}}$ & $6.90 \pm 0.00^{c}$ & $3.75 \pm 0.00^{\mathrm{bc} \dagger}$ & $18.00 \pm 0.91^{\mathrm{d}}$ \\
\hline KIN & $25.00 \pm 0.50^{\mathrm{a}}$ & $7.15 \pm 0.19^{d}$ & $1.75 \pm 0.50^{\mathrm{a} \dagger}$ & $12.07 \pm 0.81^{\mathrm{b}}$ \\
\hline $\mathrm{BA}+\mathrm{NAA}$ & $50.00 \pm 0.57^{\mathrm{bc}}$ & $4.00 \pm 0.00^{b c}$ & $1.25 \pm 0.50^{\mathrm{a} \dagger}$ & $13.00 \pm 0.11^{\mathrm{bc}}$ \\
\hline $\mathrm{KIN}+\mathrm{NAA}$ & $37.45 \pm 0.49^{\mathrm{b}}$ & $3.77 \pm 0.48^{b c}$ & $2.50 \pm 1.00^{\mathrm{b} \dagger}$ & $18.31 \pm 0.00^{\mathrm{d}}$ \\
\hline
\end{tabular}

Note: see Table 1 
The addition of growth regulators to the medium was obligatory for the initiation of regeneration in this study. These results are in contrast with those reported earlier in Malaxis acuminata (Kaur \& Bhutani 2010) and C. flaccida (Kaur \& Bhutani 2013) where the explants regenerated readily in the basal medium.

The kind and number of neo-formations in the segments depended on the growth regulator added to a medium. On the media containing cytokinin, either agarised and liquid only shoot buds were formed (Fig. 1b). On the media both agarised and liquid, supplemented with NAA, only protocorm like bodies (PLB) were formed (Table $1 \& 2$ ). PLBs formed earlier in liquid than in solid media.

In the agar-gelled medium, NAA alone stimulated regeneration response within 2.5 weeks of culture in 50\% initial explants at axillary and extra-axillary (adventive) position (Fig. 1a). In liquid MS medium NAA proved highly productive in eliciting 100 per cent regeneration inducing maximum number of supernumerary loci at node and cut surfaces within 2 weeks of culture (Figs. 1c, d). On this medium a maximum of 20 PLBs per explants were regenerated whereas on solid medium only 3.75 . The neo-formations multiplied covering almost entire segment. The PLBs did not differentiate if left in the liquid medium and started turning hyper hydrous. Therefore, immediate transfer to agarised medium of respective combination containing banana homogenate was done. After another 3 weeks of culture, PLBs multiplied profusely transforming into shoots (Figs. 1e, f). These shoots were separated and transferred to another vessel containing fresh medium where they formed into plantlets. After 4 weeks of culture, small globular masses were noticed developing at the base of the shoots (Fig. 1g). Also, PLB multiplication was also observed through budding at the surface of preformed PLB (Fig. 1h). The shoots rooted well in the same medium and developed into robust plantlets after 9 weeks of culture (Fig. 1i). The results are in accord with similar earlier findings in Dendrobium longicornu where on the shoot segments PLB-mediated regeneration occurred (Dohling et al. 2012). The suitability of auxins for PLB induction has earlier been reported in stem-node segments in Dendrobium moschatum (Kanjilal et al. 1999).

Among cytokinins, kinetin proved beneficial in inducing maximum shoot buds in $75 \%$ of explants (Table 1) through bud break (Fig. 1b). They grew into small protuberances and developed into shoots. Plantlets were formed after another 9 weeks of culture, similar to those reported earlier in Dendrobium longicornu cultures, in which the responding segments followed shoot bud-mediated regeneration (Vij et al. 2000; Košir et al. 2004; Dohling et al. 2012).

The combinations BA and KIN with NAA could initiate regeneration response only in $25 \%$ segments after 6 and 7 weeks of culture respectively in semisolid medium. In liquid medium, NAA with BA could enhance the regeneration frequency up to 50 per cent (Table 2 ).

In an earlier study, also the combination of NAA with BAP induced shoot buds in Malaxis acuminata stem-nodes (Vij \& Kaur 1998), Phalaenopsis and Doritaenopsis (Tokuhara \& Mii 1993). According to Roy \& Banerjee (2003) the combination of auxin and cytokinin invoke shoot buds in Dendrobium fimbriatum var. occulatum. Cytokinins remained less effective as they could initiate response in 25 per cent of the segments by inducing single shoots per explant after 6 and 7 weeks of culture. The segments in static liquid MS medium and its combinations with growth regulators turned brown whereas those in liquid-agitated medium, responded to regeneration.

The histological observations of the responding explant revealed meristemoids to be hypodermal in origin. The cells with dense cytoplasm and conspicuous nuclei were involved in formation of the globules (Fig 2a), which is an important characteristic feature of the embryogenic cells as earlier studied in many species belonging to genus Allium cepa (Eady et al. 1998); Lycium barbarum (Li et al. 2001); Agave sisalana (Nikam et al. 2003) and in orchid Malaxis acuminate (Kaur \& Bhutani 2010). These globules gradually grew in size, having no vascular connections with the surrounding peripheral tissues and eventually transformed into PLBs. The PLBs proliferated further to produce secondary PLBs as reported earlier (Zhao et al. 2008). 

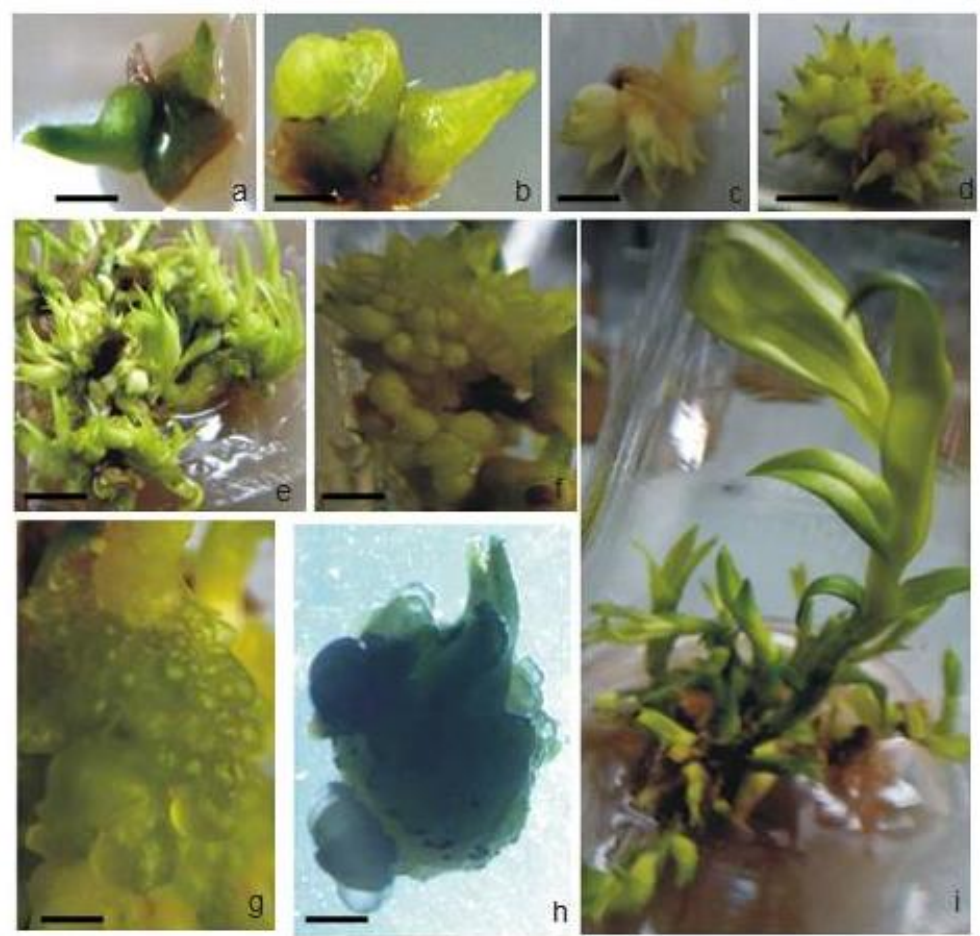

Fig. 1. In vitro propagation of Dendrobium chrysotoxum from stem-node segments in MS medium with growth regulators: (a) PLBs development in the segments at axillary and extra axillary position (adventive) in MS agar + NAA medium after 2.5 weeks (bar $=3.82 \mathrm{~mm})$, (b) shoot bud development in MS + BA agar medium after 7.0 weeks $(\mathrm{bar}=5.53 \mathrm{~mm})$, (c, d) formation of PLBs in MS liquid + NAA medium at the cut surface after 2 weeks (bar $=6.62 \mathrm{~mm})$, (e) growth of shoot buds from PLBs in MS agar + NAA medium + banana homogenate $\left(50 \mathrm{~g} \cdot \mathrm{dm}^{-3}\right)$ after 5 weeks $($ bar $=5.25 \mathrm{~m})$, (f) development of globular PLBs or somatic embryos at the base of plantlets in MS agar + NAA medium + banana homogenate $\left(50 \mathrm{~g} \cdot \mathrm{dm}^{-3}\right)$ after 6 weeks $($ bar $=5.82 \mathrm{~mm}),(\mathrm{g})$ PLBs multiplication through budding at the surface $($ bar $=$ $5.95 \mathrm{~mm}$ ), (h) development of shoots in the cultures (bar $=4.51 \mathrm{~mm}$ ), (i) development of healthy plantlets after 9 weeks

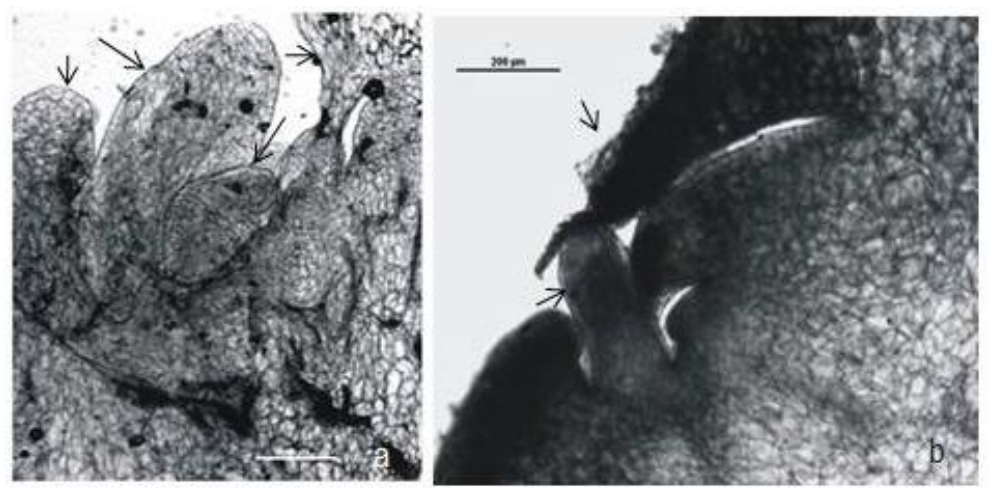

Fig. 2. Histological studies: (a) globular structures developed onto PLBs (arrow) (bar $=200 \mu \mathrm{m}$ ), (b) shoot apex with leaf primordial (arrow) (bar $=200 \mu \mathrm{m})$

Literature survey also indicates that somatic embryogenesis is an initial step of PLB regeneration in orchids (Huang et al. 2004). On the other hand, the cells divided mitotically and formed meristematic zones that developed into prominent epidermal bulges (Fig. 2a) and subsequently formed shoot bud.
Shoot apex was clearly evident (Fig 2b) as similar to that observed earlier in Bulbophyllum careyanum (Vij et al. 2000) and Malaxis acuminata (Kaur \& Bhutani 2010). In the segments, initiation of neoformations was observed as direct organogenesis process at the nodal and extra-nodal regions. In this 
study, the explants underwent both PLB and shoot buds mediated pathways of regeneration. The induction of several meristematic clusters composed of densely packed meristematic cells, forming new meristemoids on the outer surface of the explants is already on records (Ziv et al. 1998; Young et al. 2000). Arditti (1980) indicated the advantages of utilizing organic growth supplements, such as banana homogenate, coconut water and peptone on promoting growth, differentiation of protocorms, and seedling development. In the present study, $50 \mathrm{~g} \cdot \mathrm{dm}^{-3}$ banana homogenate supported healthy (robust) growth of plantlets. Similar effects was also reported for other orchids - Dendrobium and Spathoglottis kimballiana (Minea et al. 2004), Coelogyne flaccida (Kaur \& Bhutani 2014) and Dendrobium chrysotoxum initiated from seeds (Kaur \& Bhutani 2011). The promotory effect of Bh could be related to high content of carbohydrates in bananas.

Further focus will be on the acclimatization of in vitro raised plantlets of $D$. chrysotoxum and restoring these in their natural habitat. Thus, an easy protocol devised here can contribute to the mass propagation and ex-situ conservation of D. chrysotoxum.

\section{CONCLUSION}

Liquid-agitated MS medium supplemented with NAA caused PLB formation on nodal slices of D. chrysotoxum. PLBs developed into robust plantlets on agarised MS medium containing banana homogenate. Addition of cytokinin to MS medium caused shoot bud formation but this process was less effective. The protocol presented can be used for conserving this endangered and medicinally important orchid species.

\section{Acknowledgements}

Financial assistance from the Department of Science and Technology, Government of India, New Delhi, to the author is greatly acknowledged.

\section{REFERENCES}

Arditti J. 1980. Aspects of physiology of orchids. Advances in Botanical Research 7: 421-655 DOI: 10.1016/S0065-2296(08)60091-9.
Arditti J., Ernst R. 1993. Micropropagation of orchids. John Wiley and Sons, New York, USA, 682 p.

Basker S., Narmatha Bai V. 2006. Micropropagation of Coelogyne stricta (D.Don) Schltr. via pseudobulb segment cultures. Tropical and Subtropical Agroecosystems 6: 31-35.

Chen Y., Li Y., Qing C., Zhang Y., Wang L., Liu Y. 2008. 1,4,5-Trihydroxy-7-methoxy-9H-fluoren-9one, a new cytotoxic compound from Dendrobium chrysotoxum. Food Chemistry 108: 973-976. DOI: 10.1016/j.foodchem.2007.12.007.

CITES 2017. Convention on International Trade in Endangered Species of Wild Fauna and Flora, Appendices I and II. http://www.cites.org/eng/app/appendices.php

Decruse S.W., Gangaprasad A., Seeni S., Menon S.V. 2003. Micropropagation and ecorestoration of Vanda spathulata, an exquisite orchid. Plant Cell, Tissue and Organ Culture 72: 199-202. DOI: 10.1023/A:1022267009531.

Dohling S., Kumaria S., Tandon P. 2012. Multiple shoot induction from axillary bud cultures of the medicinal orchid, Dendrobium longicornu. AoB Plants, Pls 032. DOI: 10.1093/aobpla/pls032.

Eady C.C., Butler R.C., Suo Y .1998. Somatic embryogenesis and plant regeneration from immature embryo cultures of onion (Allium cepa L.). Plant Cell Reports 18: 111-116. DOI: 10.1007/s002990050541.

Gangaprasad A., Latha P.G., Seeni S. 2000. Micropropagation of terrestrial orchids, Anoectochilus sikkimensis and Anoectochilus regalis. Indian Journal of Experimental Biology 38: 149-154.

George P.S., Ravishankar G.A. 1997. In vitro multiplication of Vanilla planifolia using axillary bud explants. Plant Cell Reports 16: 490-494. DOI: 10.1007/BF01092772.

Gong Y.-Q., Fan Y., Wu D.-Z., Yang H., Hu Z.-B., Wang Z.-T. 2004. In vivo and in vitro evaluation of erianin, a novel anti-angiogenic agent. European Journal of Cancer 40: 1554-1565. DOI: 10.1016/j.ejca.2004.01.041.

Hong P.-I., Chen J.-T., Chang W.-C. 2010 Shoot development and plant regeneration from protocorm-like bodies of Zygopetalum mackayi. In Vitro Cellular and Developmental Biology - Plant 46: 306-311. DOI: 10.1007/s11627-009-9262-2.

Huang P.L., Doy Y., Jheng F.Y. 2004. Research and development on the establishment of transformation systems for Phalaenopsis orchids. Proceedings of $8^{\text {th }}$ Asia Pacific Orchid Conference, Tainan, Taiwan Orchid Growers Association, pp. 416-426. 
Janarthanam B., Seshadri S. 2008. Plantlet regeneration from leaf derived callus of Vanilla planifolia Andr. In Vitro Cellular and Developmental Biology - Plant 44: 84-89. DOI: 10.1007/s11627-008-9123-4.

Kanjilal B., De Sarker D., Mitra J., Datta K.B. 1999. Stem disc culture: development of a rapid mass propagation method for Dendrobium moschatum (Buch.-Ham.) Swartz - an endangered orchid. Current Science 77: 497-500.

Kaur S., Bhutani K.K. 2010. Micropropagation of Malaxis acuminata D. Don: a rare orchid of high therapeutic value. Open Access Journal of Medicinal and Aromatic Plants 1: 29-33.

Kaur S., Bhutani K.K. 2011. In vitro propagation of Dendrobium chrysotoxum (Lindl.). Floriculture and Ornamental Biotechnology 5: 50-56.

Kaur S., Bhutani K.K. 2013. In vitro mass propagation of ornamentally and medicinally important Coelogyne flaccida Lindl. through pseudobulb segments. Plant Tissue Culture and Biotechnology 23: 39-47. DOI: 10.3329/ptcb.v23i1.15558.

Kaur S., Bhutani K.K. 2014. In vitro conservation and asymbiotic propagation of Coelogyne flaccida (Lindl.) - a threatened orchid. Plant Biosystems 148: 935-944. DOI: 10.1080/11263504.2013.801368.

Košir P., Škof S., Luthar Z. 2004. Direct shoot regeneration from nodes of Phalaenopsis orchids. Acta Agriculturae Slovenica 83: 233-242.

Levin R., Stav R., Alper Y., Watad A.A. 1997. A technique for repeated non-axenic subculture of plant tissues in a bioreactor on liquid medium containing sucrose. Plant Tissue Culture and Biotechnology 3: 41-45.

Martin K.P. 2007. Micropropagation of the bamboo orchid (Arundina graminifolia (D. Don) Hochr.) through protocorm-like bodies using node explants. Propagation of Ornamental Plants 7: 97-100.

Medina R.D., Flachsland E.A., Gonzalez A.M., Terada G., Faloci M.M., Mroginski L.A. 2009. In vitro tuberization and plant regeneration from multinodal segment culture of Habenaria bractescens Lindl., an Argentinean wetland orchid. Plant Cell, Tissue and Organ Culture 97: 91-101. DOI: 10.1007/s11240-009-9505-2.

Minea M., Piluek C., Menakanit A., Tantiwiwat S. 2004. A study on seed germination and seedling development of Spathoglottis B1. orchids. Kasetsart Journal - Natural Science 38: 141-156.

Murashige T., Skoog F. 1962. A revised medium of rapid growth and bio assays with tobacco tissue cultures. Physiologia Plantarum 15: 473-497. DOI: 10.1111/j.1399-3054.1962.tb08052.x.
Nikam T.D., Bansude G.M., Aneesh Kumar K.C. 2003. Somatic embryogenesis in sisal (Agave sisalana Perr. ex. Engelm). Plant Cell Reports 22: 188-194. DOI: 10.1007/s00299-003-0675-9.

Puchooa D. 2004. Comparison of different culture media for the in vitro culture of Dendrobium (Orchidaceae). International Journal of Agriculture and Biology 6: 884-888.

Pyati A.N., Murthy H.N., Hahn E.J., Paek K.Y. 2002. In vitro propagation of Dendrobium macrostachyum Lindl. - a threatened orchid. Indian Journal of Experimental Biology 40: 620-623.

Rangsayatorn N. 2009. Micropropagation of Dendrobium draconis Rchb. f. from thin cross-section culture. Scientia Horticulturae 122: 662-665. DOI: 10.1016/j.scienta.2009.06.037.

Roy J., Banerjee N. 2003. Induction of callus and plant regeneration from shoot-tip explants of Dendrobium fimbriatum Lindl. var. oculatum $\mathrm{Hk}$. f. Scientia Horticulturae 97: 333-340. DOI: 10.1016/S0304-4238(02)00156-5.

Roy J., Naha S., Majumdar M., Banerjee N. 2007. Direct and callus-mediated protocorm-like body induction from shoot-tips of Dendrobium chrysotoxum Lindl. (Orchidaceae). Plant Cell, Tissue and Organ Culture 90: 31-39. DOI: 10.1007/s11240-007-9244-1.

Sandal I., Bhattacharya A., Ahuja P.S. 2001. An efficient liquid culture system for tea shoot proliferation. Plant Cell, Tissue and Organ Culture 65: 75-80. DOI: 10.1023/A:1010662306067.

Shukla B.K., Singh P., Chauhan A.S. 1998. Orchid diversity in Sikkim and its conservation. Journal of the Orchid Society of India 12: 53-76.

Smith M.A.L., Spomer L.A. 1994. Vessels, gels, liquid media, and support systems. In: Aitken-Christie J. et al. (Eds.). Automation and Environmental Control in Plant Tissue Culture, Kluwer Academic Publishers, Dordrecht, pp. 371-404. DOI: 10.1007/978-94-015-8461-6_16.

Tokuhara K., Mii M. 1993. Micropropagation of Phalaenopsis and Doritaenopsis by culturing shoot tips of flower stalk buds. Plant Cell Reports 13: 711. DOI: 10.1007/BF00232306.

Vij S.P., Kaur P. 1998. Micropropagation of therapeutically important orchids: Malaxis acuminata D. don. Journal of the Orchid Society of India 12: 89-93.

Vij S.P., Kher A., Pathak P. 2000. Micropropagation of Bulbophyllum careyanum (Hook.) Spreng. using pseudobulb segments. Journal of the Orchid Society of India 14: 47-56. 
Xu H., Liu J., Wang Z-T., Xu D-R., Ding J-Y. 2001. Studies on tissue culture of Dendrobium chrysotoxum Lindl in vitro. Zhongguo Zhong Yao Za Zhi 26: 378-381. [in Chinese with English abstract

Yang H., Chou G-X., Wang Z-T., Guo Y-W., Hu Z-B., $\mathrm{Xu}$ L-S. 2004. Two new compounds from Dendrobium chrysotoxum. Helvetica Chimica Acta 87: 394-399. DOI: 10.1002/hlca.200490037.

Young P.S., Murthy H.N., Paek K.Y. 2000. Mass multiplication of protocorm-like bodies using bioreactor system and subsequent plant regeneration in Phalaenopsis. Plant Cell, Tissue and Organ Culture 63: 67-72. DOI: 10.1023/A:1006420116883.

Zhao Y., Son Y.-O., Kim S.-S., Jang Y.-S., Lee J.-C. 2007. Antioxidant and anti-hypoglycemic activity of polysaccharide isolated from Dendrobium chrysotoxum Lindl. Journal of Biochemistry and Molecular Biology 40: 670-677. DOI: 10.5483/bmbrep.2007.40.5.670.

Zhao P., Wu F., Feng F-S., Wang W-J. 2008. Protocormlike body (PLB) formation and plant regeneration from the callus culture of Dendrobium candidum Wall ex Lindl. In Vitro Cellular and Developmental Biology - Plant 44: 178-185. DOI: 10.1007/s11627-007-9101-2.

Ziv M., Ronen G., Raviv M. 1998. Proliferation of meristematic clusters in disposable presterilized plastic bioreactors for large-scale micropropagation of plants. In Vitro Cellular and Developmental Biology - Plant 34: 152-158. DOI: 10.1007/BF02822781. 